\title{
Teaching NeuroImages: Pupil-sparing compression of oculomotor nerve by posterior cerebral artery vessel
}

Anfei Li, Anika Tandon, MD, Apostolos J. Tsiouris, MD, Marc J. Dinkin, MD, and Cristiano Oliveira, MD Neurology ${ }^{\circledR}$ 2020;94:e1450-e1451. doi:10.1212/WNL.0000000000009181

Figure 1 Compression of the left CNIII nerve by left posterior cerebral artery
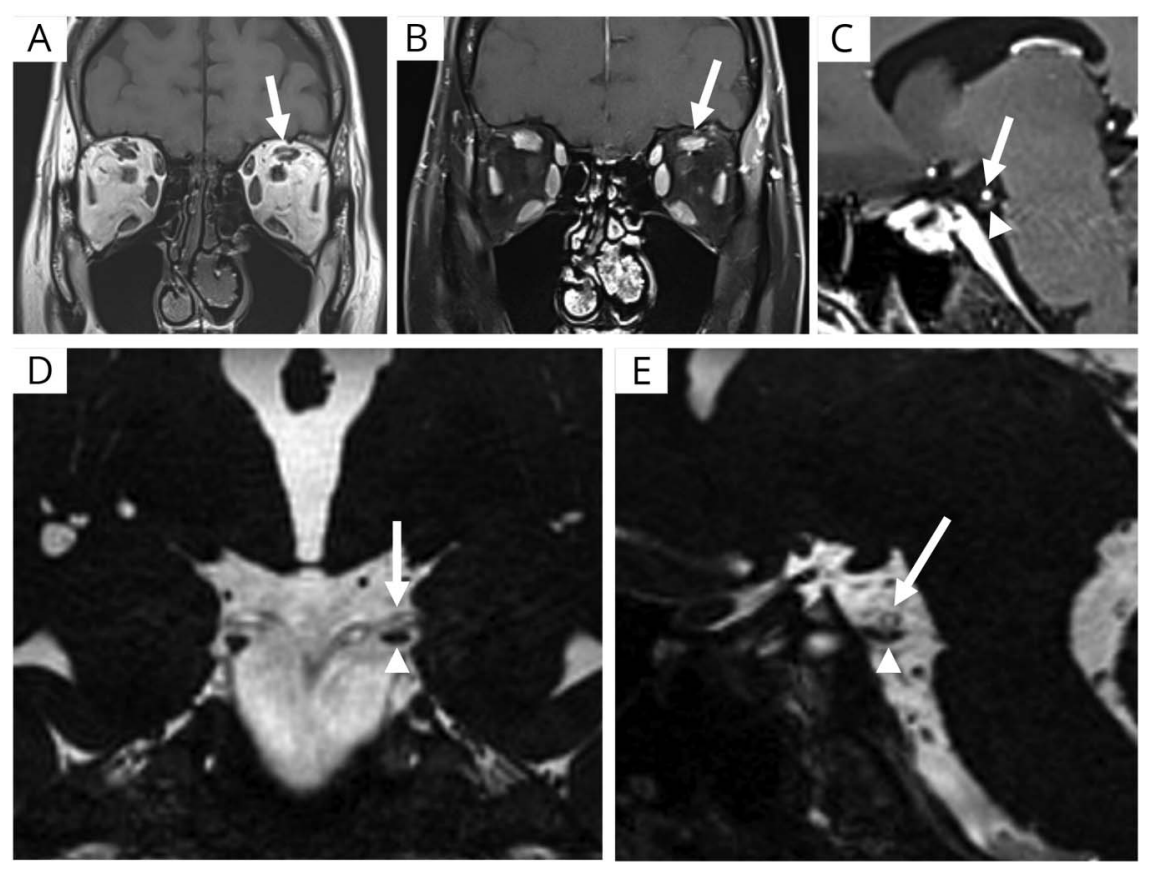

(A, B) Isolated asymmetric atrophy of the left superior rectus muscle (arrows). (C) Left posterior cerebral artery in cross-section (arrow) impinges upon the left CNIII (arrowhead). (D, E) Asymmetric flattening of the left CNIII (arrowheads) by the left posterior cerebral artery (arrows).

A 54-year-old woman presented with a 30-year history of worsening left blepharoptosis. Neuroophthalmic examination was significant for blepharoptosis, limited levator function, and supraduction in the left eye with left hypotropia, and normal pupils without diplopia. MRI brain/orbits revealed subtle atrophy of the left superior rectus (figure 1, A and B), without any orbital pathology. Superior compression of the left oculomotor nerve by the posterior cerebral artery (PCA) was observed (figure 1, C-E). Given the microanatomy of oculomotor nerve in the cistern space, ${ }^{1,2}$ this is a rare selective compression of the superolateral oculomotor nerve by the PCA vessel (figure 2), sparing the superomedial parasympathetic limb.

\section{Correspondence}

Dr. Oliveira

cro9004@med.cornell.edu

\section{MORE ONLINE}

\section{$\rightarrow$ Teaching slides}

links.lww.com/WNL/ B67

From the Division of Neuro-Ophthalmology (A.T., M.J.D., C.O.), Department of Ophthalmology, and Department of Radiology (A.J.T.), Weill Cornell Medicine (A.L.), New York, NY, Go to Neurology.org/N for full disclosures. Funding information and disclosures deemed relevant by the authors, if any, are provided at the end of the article. 
Figure 2 Illustration of the CNIII microanatomy (not to scale)

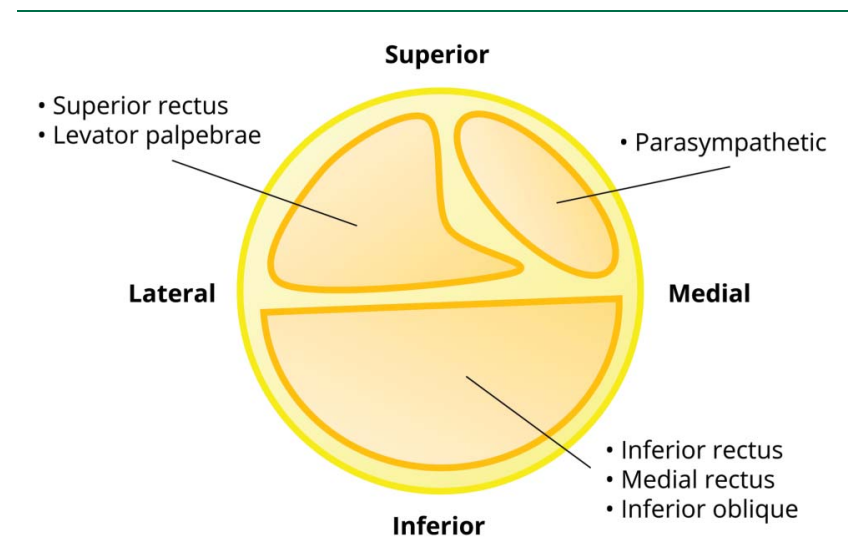

Image is constructed based on similar images in Brazis. ${ }^{3}$

\section{Study funding}

No targeted funding reported.

\section{Disclosure}

The authors report no disclosures relevant to the manuscript. Go to Neurology.org/N for full disclosures.
Appendix Authors

\begin{tabular}{lll}
\hline Name & Location & Contribution \\
\hline Anfei Li & $\begin{array}{l}\text { Weill Cornell } \\
\text { Medicine, New } \\
\text { York, NY }\end{array}$ & $\begin{array}{l}\text { Interpretation of data and drafting } \\
\text { of the manuscript }\end{array}$ \\
\hline $\begin{array}{l}\text { Anika } \\
\text { Tandon, MD }\end{array}$ & $\begin{array}{l}\text { Weill Cornell } \\
\text { Medicine, New } \\
\text { York, NY }\end{array}$ & $\begin{array}{l}\text { Interpretation of the data and } \\
\text { revision of the manuscript }\end{array}$ \\
\hline $\begin{array}{l}\text { Apostolos J. } \\
\text { Tsiouris, MD }\end{array}$ & $\begin{array}{l}\text { Weill Cornell } \\
\text { Medicine, New }\end{array}$ & $\begin{array}{l}\text { Generation of imaging data } \\
\text { York, NY }\end{array}$ \\
$\begin{array}{lll}\text { Marc J. } \\
\text { Dinkin, MD }\end{array}$ & $\begin{array}{l}\text { Weill Cornell } \\
\text { Medicine, New } \\
\text { York, NY }\end{array}$ & $\begin{array}{l}\text { Design of the study, interpretation } \\
\text { of the data, and revision of the } \\
\text { manuscript }\end{array}$ \\
\hline $\begin{array}{l}\text { Cristiano } \\
\text { Oliveira, MD }\end{array}$ & $\begin{array}{l}\text { Weill Cornell } \\
\text { Medicine, New } \\
\text { York, NY }\end{array}$ & $\begin{array}{l}\text { Design of the study, interpretation } \\
\text { of the data, and revision of the } \\
\text { manuscript }\end{array}$ \\
\hline
\end{tabular}

\section{References}

1. Miyazaki S. Location of motoneurons in the oculomotor nucleus and the course of their axons in the oculomotor nerve. Brain Res 1985;348:57-63.

2. Atasever A, Durgun B, Celik HH, Yilmaz E. Somatotopic organization of the axons innervating the superior rectus muscle in the oculomotor nerve of the rat. Cells Tissues Organs 1993;146:251-254.

3. Brazis PW. Localization of lesions of the oculomotor nerve: recent concepts. Mayo Clin Proc 1991;66;1029-1035. Review. 


\section{Neurology}

\section{Teaching NeuroImages: Pupil-sparing compression of oculomotor nerve by posterior cerebral artery vessel}

Anfei Li, Anika Tandon, Apostolos J. Tsiouris, et al.

Neurology 2020;94;e1450-e1451 Published Online before print March 9, 2020

DOI 10.1212/WNL.0000000000009181

This information is current as of March 9, 2020

\section{Updated Information \&}

Services

References

Subspecialty Collections

Permissions \& Licensing

Reprints including high resolution figures, can be found at: http://n.neurology.org/content/94/13/e1450.full

This article cites 3 articles, 0 of which you can access for free at: http://n.neurology.org/content/94/13/e1450.full\#ref-list-1

This article, along with others on similar topics, appears in the following collection(s):

Eyelids

http://n.neurology.org/cgi/collection/eyelids

MRI

http://n.neurology.org/cgi/collection/mri

Ocular motility

http://n.neurology.org/cgi/collection/ocular_motility

Information about reproducing this article in parts (figures,tables) or in its entirety can be found online at:

http://www.neurology.org/about/about_the_journal\#permissions

Information about ordering reprints can be found online:

http://n.neurology.org/subscribers/advertise

Neurology ${ }^{\circledR}$ is the official journal of the American Academy of Neurology. Published continuously since 1951, it is now a weekly with 48 issues per year. Copyright () 2020 American Academy of Neurology. All rights reserved. Print ISSN: 0028-3878. Online ISSN: 1526-632X.

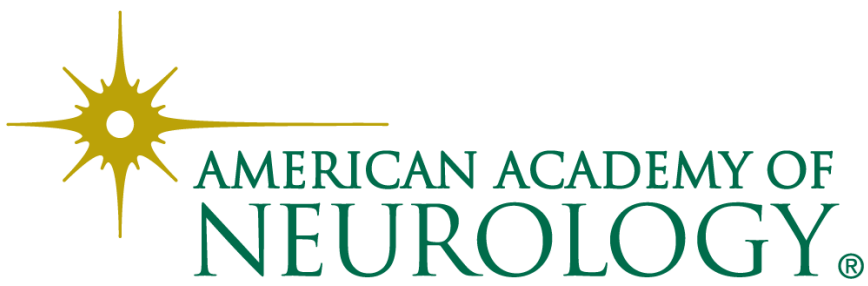

